\title{
Defaunation affects Astrocaryum gratum (Arecales: Arecaceae) seed survivorship in a sub-montane tropical forest
}

\author{
Enzo Aliaga-Rossel ${ }^{1 *} \&$ José Manuel Fragoso ${ }^{2}$
}

1. University of Hawaii, 3190 Maile Way. Honolulu Hi 96822.USA. Current address: Associate Researcher Institute of Ecology- Universidad Mayor de San Andres, Calle 27, Campus Universitario S/N, Cota Cota. La Paz- Bolivia; ealiagar@hotmail.com

2. Biology Department, 260 Panama St, Stanford University, 94305 CA, USA; fragoso@stanford.edu

* Correspondence

Received 20-I-2014. Corrected 01-IX-2014. Accepted 09-X-2014.

\begin{abstract}
Animal-plant interactions in Neotropical forests are complex processes. Within these processes, mid- to large-sized mammals consume fruits and seeds from several species; however, because of their size these mammals are overhunted, resulting in defaunated forests. Our objective was to evaluate and compare seed removal and survivorship in a forest with no hunting, a forest with moderate or reduced hunting, and a forest with higher hunting pressure. We examined the interaction between Astrocaryum gratum and white lipped peccary (Tayassu pecari) to tease apart the defaunation process. To isolate and evaluate mammal seed removal rates and to identify the causes of mortality on A.gratum, under the three different hunting pressures forests, we used exclosures in each one. In four different forest-patches for each forest, we positioned a block-treatment consisting of three exclosures (total exclusion, peccary exclusion, and control), randomly distributed $5 \mathrm{~m}$ apart and the block-treatments spaced 50-75m apart from one another. We established 15 treatments in total for each patch ( 5 blocks per patch). There were 20 blocks within each forest type. For total exclusion, all vertebrates were excluded using galvanized wire mesh exclosures. The second, the peccary exclusion, was designed to stop peccaries from entering treatment units, providing access only to small vertebrates; larger mammals were able to access the treatment unit by reaching over the sides and the open top; finally, the Control allowed full access for all mammals. Fresh A. gratum fruits were collected from the forest floor under different adult trees throughout the study area. In each exclosure treatment, twenty A.gratum seeds were placed, and their removal was recorded. In total, 3600 seeds were analyzed. Seed survival was lower in unhunted forest compared to areas with moderate hunting and forest with a higher hunt pressure, supporting the hypothesis of the importance of mammals in seed removal. From the initial 400 seeds left for each control exclosure in each type of forest, there was a significant difference between the seed removal; $1.75 \%$ seeds in the unhunted forest remained; $43.5 \%$ in the moderately hunted forest, and $48.5 \%$ in hunted forest. The main cause of seed mortality was white lipped peccaries; while in the forests without them, the main removal was caused by rodents and a higher insect infection was observed in the heavily hunted forest. Our results indicated that defaunation affects seed survivorship. Rev. Biol. Trop. 63 (1): 57-67. Epub 2015 March 01.
\end{abstract}

Key words: defaunation, empty forest, half-empty forest, Bolivia, chonta palm.

Animal-plant interactions in Neotropical forests are complex processes not fully understood. Within these, there are several factors that influence seed survivorship and depredation rates, such as wildlife density, herbivore species composition, presence of predators, seed concentration, and parent tree density
(Forget, \& Cuijpers, 2008; Dracxler, Pires, \& Fernandez, 2011). The majority of terrestrial mammals that consume palm fruits are seed dispersers, but many can also be seed predators (Smythe, 1989; Silvius, 2002). Seed dispersal by animals is widely recognized as a significant influence on vegetation, seeds are dispersed 
from parent plants helping them to avoid competition for light, space, and colonizing new suitable habitats (Janzen, 1970).

Many large-seeded neotropical plant species have co-evolved with medium and large animals for their primary dispersal, but also secondary dispersal which occurs when seeds are moved from where they were deposited by primary dispersal to a second location. Often mid- to large-sized mammals like tapir (Tapirus spp.) or agoutis (Dasyprocta spp.) are attracted to fruits on the forest floor and they then move seeds longer distances, sometimes engaging in scatter-hoarding or seed caching behaviors (Jansen, Elschot, Verkerk, \& Wright, 2010). When dispersed long distances, seeds had higher survivorship with lower interspecific competition and invertebrate infestation; e.g., Coleoptera; Bruchids, Scolytine. (Janzen, 1970; Quiroga-Castro, \& Roldán, 2001; Galetti, Donatti, Pires, Guimarães, \& Jordano, 2006; Galvez, \& Jansen, 2007; Dracxler et al., 2011).

Seed predation is an important animalplant relationship that affects the reproductive success of individual species, plant population dynamics and plant community structure (Janzen, 1970). Many tropical wildlife including mammals, birds and insects are known seed predators (Smythe, 1989; Dracxler et al., 2011). Therefore, the composition of the animal fauna in a forest will have different impacts on seed survivorship, and the removal of medium to large mammals by over-hunting or habitat loss, will have different effects on tree populations and the structure of the forest (Roldán, \& Simonetti, 2001; Silman, Terborgh, \& Kiltie, 2003; Wright, 2003; Beckman, \& Muller-Landau, 2007; Galvez, \& Jansen, 2007; Holbrook, \& Loiselle, 2009; Dracxler et al., 2011).

The chonta palm (Astrocaryum gratum, Kahn, \& Millan, 1992) is a widely distributed species in sub-montane forests in Peru and Bolivia. It produces up to three infructescences (approximately $700 \pm 237.3$ fruits) per year, which ripens from December to April (AliagaRossel, 2011a). The orange-yellowish fruit are 4 to $6.7 \mathrm{~cm}$ long, $3-4 \mathrm{~cm}$ wide, and the fresh succulent pulp, which covers a single seed, is very aromatic (Aliaga-Rossel, 2011a); A. gratum depends on wildlife for dispersal, and fruits on the ground attract a large number of terrestrial mid- and large-sized animals capable of both dispersal and predation as it has been shown with other plant species (Holbrook, \& Loiselle, 2009). The Astrocaryum endocarp and seed are hard to crack, with only a handful of species able to open and consume them, like white lipped peccaries (Tayassu pecari), agouti, and a few other rodents (Asquith Wright, \& Clauss, 1997; Aliaga-Rossel, Kays, \& Fragoso, 2008).

The objective of this research was to evaluate and compare seed removal and survivorship of the Chonta Palm caused by terrestrial mammals in a forest with no hunting, a forest with moderate or reduced hunting, and a forest with higher hunting pressure. We predicted that in the absence of the main seed predator the white lipped peccary, seed removal, and mortality, would be lower in the unhunted forest than in the moderately hunted or hunted forests (Silman et al., 2003). We focused on the role of the white-lipped peccary (WLP; Tayassu pecari Link 1795) as a model because it is an ecologically important species, forming large herds and requiring extended territory areas, up to $200 \mathrm{~km}^{2}$ (Fragoso, 1998; Reyna-Hurtado et al., 2008). During foraging, they remove the entire upper layer of soil and leaf litter resulting in damage and mortality to thousands of seedlings of many different species, and their movements through high-density patches of adult palm trees limit seed survival (Fragoso, 1998; Reyna-Hurtado et al., 2008). Also, peccaries are a preferred game species highly susceptible to hunting pressure. In areas where people are present, white lipped peccaries are generally absent or rare (Reyna-Hurtado et al., 2008; Aliaga-Rossel, 2011b).

\section{MATERIALS AND METHODS}

Study site: This study was conducted in Madidi National Park and Natural Area of Integrated Management, Bolivia (13²0'00" S - 6 $\left.8^{\circ} 10^{\prime} \mathrm{W}, 69^{\circ} 10^{\prime} \mathrm{W}-14^{\circ} 00^{\prime} \mathrm{S}\right)$, and the Pilón Lajas Biosphere Reserve and Indigenous 
Territory, Bolivia $\left(14^{\circ} 25^{\prime} \mathrm{S}-66^{\circ} 55^{\prime} \mathrm{W}, 15^{\circ} 27^{\prime} \mathrm{S}\right.$ - $67^{\circ} 40^{\prime} \mathrm{W}$ ) inhabited by the indigenous community of Tsimane-Moseten of Asunción del Quiquibey. These are adjacent to one another, with similar habitats and ecosystems. Access to both sites is by river only (6-10h and $2 \mathrm{~h}$ respectively) from the small town of Rurrenabaque, Department of the Beni-Bolivia.

The mean precipitation in this region is estimated at over $2000 \mathrm{~mm}$ annually. The mean annual temperature is $26^{\circ} \mathrm{C}$ (Navarro, \& Maldonado, 2004), the area is tropical, with well-defined dry (June to September) and rainy (October to April) seasons (AliagaRossel, 2011a). The vegetation in the region is a piedmont sub-montane evergreen forest (Navarro, \& Maldonado, 2004) that transitions into moist lowland forest with Amazonian affinities. The floristic diversity of the lowland forest is considerable, with high densities of palm species (Navarro, \& Maldonado, 2004). The experiments were set at the beginning of the peak of the fruiting season, during the early raining season.

According to three different levels of defaunation, this study was conducted in the following forest categories: hunted forests with high levels of hunting activity for subsistence uses located in Asunción del Quiquibey indigenous community (Pilon Lajas); moderately hunted forests altered to a lesser extent, including moderate levels of hunting generally distant $>10 \mathrm{~km}$ from the communities; unhunted forests with intact terrestrial mammal communities (unhunted), in Madidi National Park. Therefore, with higher composition and density of medium to large size mammals in the unhunted forest (Pérez, 2008).

To isolate and evaluate mammal seed removal rates and to identify the causes of mortality on A. gratum, under different hunting pressures (hunted, moderately and unhunted forests) we used exclosures treatments in each forest. We randomly selected four different patches at least $1.5 \mathrm{~km}$ apart from one another. In each patch we positioned a block-treatment consisting of three exclosures (total exclusion, peccary exclusion, and control) randomly distributed $5 \mathrm{~m}$ apart, block-treatments spaced 50-75m apart from one another. We established 15 block-treatments in total for each patch ( 5 blocks per patch). These exclosure were modified from Antonik (2005) and Silman et al. (2003). There were 20 blocks within each hunting pressure forest. Because seed mortality is often higher under and near parent trees, exclosure were set at least $50 \mathrm{~m}$ away from adult palms (Janzen, 1970).

Exclosures were applied for seed survivorship experiments in each forest; for the "total exclusion", all vertebrates were excluded using galvanized wire mesh exclosures $(1 \mathrm{x} 1 \mathrm{~m}, 50 \mathrm{~cm}$ high; less than $2 \mathrm{~cm}^{2}$ mesh); the same size mesh was used to cover the top of exclosures to exclude climbing mammals like squirrels or rats. The wire mesh was staked into the soil to prevent any mammals burrowing underneath. The second exclosure was the partial exclosure ("peccary exclosure"). The peccary exclosure were constructed of the same galvanized wire fencing $(1 \mathrm{x} 1 \mathrm{~m}$, running $20 \mathrm{~cm}$ above the ground to $50 \mathrm{~cm}$ tall; $2 \mathrm{~cm}^{2}$ mesh). This exclosure design stopped peccaries from entering treatment units, providing access only to small vertebrates, i.e. mammals such as agoutis $(D$. punctata) and other rodents (i.e., Proechimys spp., Sciurus spp.). Larger mammals such as deer and tapir were able to access the treatment unit by reaching over the open top. Peccaries do not have long necks and cannot raise their heads to forage so they could not reach into the exclosures. These total and peccary exclosures prevented access by both collared peccaries (Tayassu tajacu Linnaeus 1758) and whitelipped peccaries ( $T$. pecari). Finally, the open control (Control) allowed full access for all terrestrial mammals.

Fresh A. gratum fruits were collected opportunistically from the forest floor of different adult trees throughout the study area, mixing all the fruits. For the experiment, we manually removed the pulp (exo-mesocarp) to reduce the attraction for frugivores and insects, and washed the endocarp, discarding any seed that might be damaged, rotten, or that would had insect holes (Aliaga-Rossel, 2011b). 
The seeds were then placed in the treatment exclosures (Jansen et al., 2010). The area around each block was cleared (up to $10 \mathrm{~m}$ ) of any possible $A$. gratum seeds until no seeds were found, to easily locate and recover tested seeds that may had been moved and deposited nearby. Seeds are large and heavy, with a hard wooden endocarp (1.5-3mm thick) that could not be easily washed away by rain or wind.

In each exclosure we set 20 seeds on the ground surface and separated each at least $10-15 \mathrm{~cm}$ from each other; with a total of 400 seeds for each patch. A total of 1200 seeds for each forest were tested (unhunted forest; moderately hunted forest and hunted forest), yielding a total of 3600 seeds. To document survivorship and the removal rates, and seed mortality, the treatments were revisited after a week, two weeks, a month, two months and three months. At each visit we recorded the number of remaining seeds. We assumed that in unhunted forest, the seeds would be removed quicker, because of the higher density of mammals, while in the hunted area; removal should be slower, because of the absence of the main seed predator.

Cintra and Horna (1997) have found that for tropical tree species, seed removal correlates strongly with predation, but Vander Wall, Kuhn and Beck (2005), indicated that seed removal studies may have misinterpreted seed predation, because they have focused only in the initial step of seed fate, ignoring secondary dispersion, consequently, it is inappropriate to assume that removed seeds have been consumed by seed predators. We considered seed predation, when examining seeds these had been opened, or removed and found within the $10 \mathrm{~m}$ around the exclosures. Seeds that were missing were scored as unknown; and after three months, at the end of the experiment, all remaining seeds were collected, opened, and if seed endosperm was intact, we scored it as viable and a survivor (Silvius, 2002).

In addition, to evaluate the presence of mammal fruit or seed-predators in this study, we recorded and identified mammal presence and mammal tracks (Aliaga-Rossel, 2011b).
In this study mammal predation was determined by: 1) the teeth marks left by larger rodents (e.g., agoutis) on the hard endocarp; 2) remains of the destroyed endocarp and teeth marks caused by peccaries and also their tracks around the exclosures. Teeth marks on the endocarp caused by smaller rodents, such as Sciurus spp. and Proechimys spp., were difficult to identify and therefore were gathered in a single group. Because small holes are indicators of insect predation, we also noted holes in the endocarp (Silvius, \& Fragoso, 2002; Galvez, \& Jansen, 2007). We recorded rotten, attacked by fungus or nonviable seeds, based on the exterior seed appearance and finally the inviability of the seed. When a cause of mortality was difficult to determine or if seed was removed but its fate could not be determined, we categorized them as 'unknown'. A factorial ANOVA was conducted to determine if statistical differences in seed removal were present among treatments and forest types within the patches and treatments also included; and to determine the effects of forest, ANOVAs were conducted comparing the three forests, separately for each exclosure type. Statistical analysis was performed using Minitab statistical software package.

\section{RESULTS}

Seed survival and predation in three forests with different degrees of defaunation: At the end of the experiment, all treatments (including total exclosure) resulted in different degrees of seed survivorship (therefore, seed removal) (Fig. 1).

The factorial ANOVA indicated a significant interaction between exclosure type and forest, as well as significant main effects of both forest and exclosure type. To explore this interaction, ANOVAs were conducted comparing the three forests, separately for each exclosure type; the results were very different among the exclosure treatments (Table 1). In the control of each forest type presented a strongly different survivorship pattern; from the initial 400 seeds tested in the control, only seven seeds 


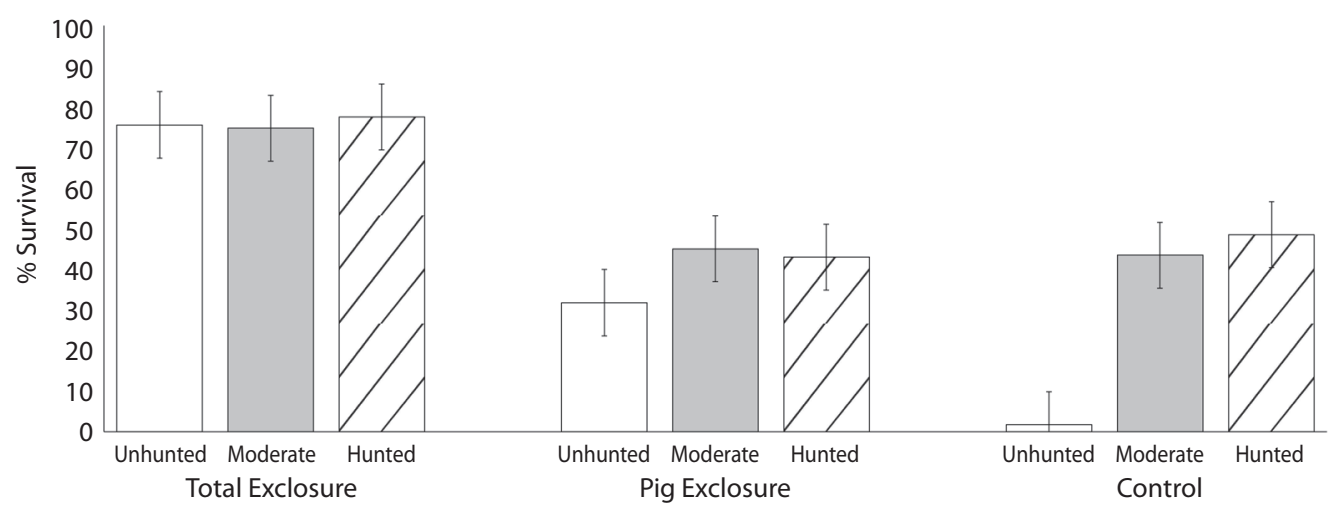

Fig. 1. Percent of the total Astrocaryum gratum seeds that survived at the end of the experiment in the three type of forests (unhunted, moderately and hunted forest), with three exclosure treatments each: a) Total exclosure; b) Peccary exclosure; c) Control (no exclosure).

TABLE 1

Factorial analysis of variance for Astrocaryum gratum seeds

\begin{tabular}{lcccccc}
\multicolumn{1}{c}{ Source } & DF & Seq SS & Adj SS & Adj MS & F & p \\
Forest & 2 & 584.54 & 584.54 & 292.27 & 5.54 & 0.027 \\
Patch (Forest) & 9 & 474.58 & 474.58 & 52.73 & 2.72 & 0.012 \\
Block (Forest Patch) & 48 & 929.07 & 929.07 & 19.36 & 1.37 & 0.091 \\
Exclosure & 2 & 2692.98 & 2692.98 & 1346.49 & 94.96 & 0.000 \\
Forest* Exclosure & 4 & 554.62 & 554.62 & 138.66 & 9.78 & 0.000 \\
Error & 114 & 1616.4 & 1616.4 & 14.18 & & \\
Total & 179 & 6852.19 & & & & \\
\hline
\end{tabular}

$\mathrm{DF}=$ Degrees of freedom; SeqSS= sequential sum of squares; AdjSS= Adjusted sum of squares; F= F-statistic; $\mathrm{P}=\mathrm{P}$-value.

$(1.75 \%)$ in the unhunted forest remained intact, $174(43.5 \%)$ seeds were intact in the moderately hunted forest, and 194 (48.5\%) seeds were intact in the hunted forest; a significant difference in seed removal between the three forest types was detected (control excl: Forest $\mathrm{F}=20.5$, d.f. $=2.9, \mathrm{p}<0.0005$ ). For the "peccaries exclosure treatment" the percentage of removal in the first month showed no significant difference for hunted and moderately hunted forest types, with a percent survivorship of $86.5 \%$ and $88.25 \%$ respectively, but in the intact forest it was $60.5 \%$; for the third month. Seed survivorship was $31.75 \%$ in the unhunted forest, $45 \%$ in the moderately hunted, and $43 \%$ in the hunted. However, no significant differences were found among these type of forests (peccary excl:
Forest $\mathrm{F}=0.82$, d.f. $=2.9, \mathrm{p}=0.470$ ). For the "total exclosure treatment", neither of the time periods studied presented a difference in seed mortality in the three forest types; at the end of the experiments $77.5 \%$ of seeds survived for the unhunted, $74.75 \%$ for the moderately hunted, and $75.5 \%$ for the hunted forest (Total excl: Forest $\mathrm{F}=0.13$, d.f. $=2.9$, $\mathrm{p}=0.879$ ). When removal rates were compared over time in the control, removal rates for the unhunted forest were $60.25 \%$ for the first week, $73.25 \%$ at week two, and $98.25 \%$ for the third month, showing a fast removal rate, decreasing the survivorship to less than $1.7 \%$ (Fig. 2).

Causes of $A$. gratum seed removal and depredation: The highest seed mortality 

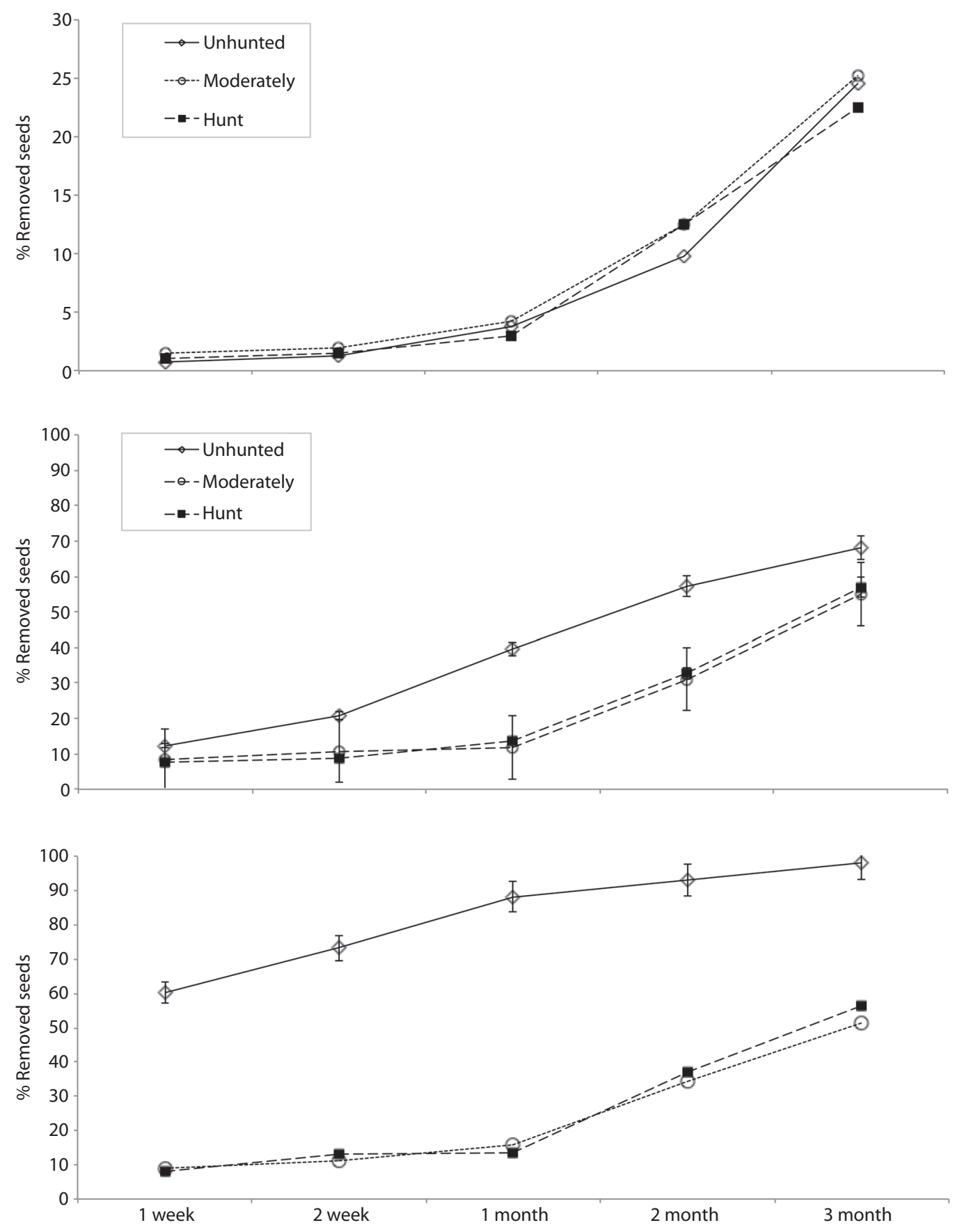

Fig. 2. Percent Astrocaryum gratum seeds removed in three forests (unhunted, moderately and hunted forest) with three treatments each: a) Total exclosure; b) Peccary exclosure; c) Control (no exclosure). Seed reviewed during the first week; week 2; first month; second and third month. 
TABLE 2

Causes of Astrocaryum gratum depredation, in percent, caused by peccari, rodents, fungus, insects, unknown causes. Three treatments each forest: Total exclosure; Pecary exclosure; Control (no exclosure), in three forests type unhunted forest, moderately hunted-forest and hunted forest

\begin{tabular}{|c|c|c|c|c|c|c|c|c|c|c|c|c|c|c|c|}
\hline \multirow{2}{*}{ Block } & \multicolumn{3}{|c|}{ Peccary } & \multicolumn{3}{|c|}{ Rodents } & \multicolumn{3}{|c|}{ Fungus } & \multicolumn{3}{|c|}{ Insect } & \multicolumn{3}{|c|}{ Unknown } \\
\hline & UH & Mo & HT & $\mathrm{UH}$ & Mo & HT & UH & Mo & HT & $\mathrm{UH}$ & Mo & HT & $\mathrm{UH}$ & Mo & HT \\
\hline Total & 0 & 0 & 0 & 0 & 0 & 0 & 10.25 & 11.25 & 8 & 2.25 & 4.5 & 4 & 12 & 9.5 & 10.5 \\
\hline Peccary & 4.25 & 0 & 0 & 25 & 19.5 & 13.75 & 6.75 & 13.25 & 16.5 & 2.75 & 6.5 & 6.75 & 29.5 & 15.75 & 2 \\
\hline Control & 68.25 & 1.25 & 0 & 14 & 20.25 & 15 & 4.5 & 11 & 13.25 & 2.25 & 7 & 8.25 & 9.25 & 17 & 15 \\
\hline
\end{tabular}

Peccari=White-lipped peccary, rodents, fungus, insects, unknown causes. Block for each forest: Total=Total exclosure; Peccary: Pecary exclosure; Control (no exclosure). Three forests type; were $\mathrm{UH}=$ unhunted forest, $\mathrm{Mo}=$ moderately huntedforest and HT= hunted forest.

registered corresponded to the control in the unhunted forest; where WLP removed most of the seeds $(69.46 \%)$ confirmed by evidence of the peccaries' activity of soil removal, tracks and damaged seeds. Only $2.21 \%$ of the damage in the moderately hunted forest was caused by peccaries, and there was no evidence of collared or WLP predation in the hunted area where their population was extirpated (AliagaRossel, 2011b). Comparing seed removal by rodents in the different hunting pressure forest, this was higher in the moderately hunted and in the hunted forest, and lower in the unhunted forest (Table 2).

In the "peccaries exclosure treatment" simulating a moderately hunted forest, where the exclosures allowed rodents to have access to the seeds, the proportion of seeds depredated by agoutis, squirrels and other rodents for the moderately hunted forest (35.45\%) was similar to the control in the same forest $(35.84 \%)$, and in the unhunted forest $(36.6 \%)$. Seeds depredated by rodents from the exclosure treatments were found with unmistakable teeth marks, highlighting the rodents' role as seed predators in the absence of peccaries. These seeds were found in a $5-10 \mathrm{~m}$ radius from each exclosure. Four seeds that appeared to be hoarded by rodents were found in the area but we did not include them in the analysis and the fate of these seeds was not followed.

The "total exclosures" worked well and there was no sign of mammal or any vertebrate activity inside the exclosures. Fungus infection, rotten seeds and insect attacks were the main causes of mortality (Table 2). As we did not open the exclosures to examine seeds, we did not detect a visible insect attack during the first two months in the three types of forests. The earliest insect attack was clearly registered at the beginning of the second month in the hunted forest. Moderately hunted and hunted forest types demonstrated higher rates of insect predation (12.38\% and $16.01 \%$ respectively); fungus and other pathogens attacks did not appear to differ among forest types (Table 2).

\section{DISCUSSION}

The study design and the use of exclosures isolated the effects of different vertebrates and allowed comparison among forests affected by different hunting pressure (unhunted, moderately and hunted forest). We found a significantly higher seed removal and seed mortality rate in the unhunted forest compared to forests where white-lipped peccary the main seed predator was extirpated (Pérez, 2008). The critical period for seed removal and mortality in the unhunted forest was during the first weeks (more than 55\% of seeds placed in the control were removed), which is similar to that observed for Astrocaryum murumuru (Cintra, 1997).

At the end of the experiment, open controls in the unhunted forest demonstrated higher seed removal rates $(98.25 \%)$ than open 
controls in the hunted or moderately hunted forests. This result is similar to what has been observed in other Neotropical forests where seed mortality of other Astrocaryum species reaches 95-100\% (Janzen, 1970; Smythe, 1989; Cintra, 1997; Cintra, \& Horna, 1997; Silman et al., 2003). The moderately hunted and hunted forests showed similar removal rates over time (56.5\% and $51.5 \%$, at the end of the experiment respectively), with higher seed survival than in the unhunted forest. In the "moderately hunted" forest, we detected a very low removal rate $(2 \%)$ caused by peccaries, based in the distinctive tracks and signs, this was probably a small troop of white-lipped (WLP) or collared peccaries (Peccary tajacu), which were present in very low densities in the area (Pérez, 2008; Aliaga-Rossel, \& Painter, 2010), and the effect on seed removal was therefore insignificant, compared with the higher removal rate by WLP in the unhunted forest.

Independent of the hunting pressure, the total exclusion treatment presented higher mortality from pathogens or unknown causes. The total exclusion simulates a hypothetical scenario where the forests lack all vertebrates including small rodents and squirrels. Therefore, the sources of mortality would only be weather conditions, physical damage, insects, fungus, and other seed pathogens.

The peccary exclosure was very effective, especially when tested in the unhunted forest where peccary densities are high (Aliaga-Rossel, 2011b). In one occasion, peccaries pushed at the sides of the exclosures and reached the seeds in a single place where two seeds were removed and killed. The "peccary exclosure" in the three types of forest had similar seed survivorship as the control treatment in the moderately hunted forest, because the main seed predator was excluded by the experiment. In the experiment, the peccary exclosures also demonstrated a similar seed survival to the control in a hunted forest. The absence of other large mammals (deer or tapirs) might have an effect on seed dispersal (not tested here) but still not have a relevant impact in seed mortality because they feed on $A$. gratum fruits but we did not observe them as seed predators. As observed in the results, the extirpation of a main seed predator did have a major impact on $A$. gratum seed survivorship (1.75\% of survivorship vs. $48.5 \%$ in the unhunted forest); consequently, such patterns will likely support a higher number of rodents that they may be able to get access to more seeds.

For A. murumuru, there was higher survival when seeds were at lower densities and greater distances from parent trees (Cintra, 1997). In the hunted forests, a higher seedling density of A. gratum of different cohorts was observed close to parental trees (AliagaRossel, 2011b). This higher seedling density also suggests that the reduction of mammals increased the chances for A. gratum seeds to survive and to recruit to the seedling stage (Aliaga-Rossel, 2011b).

When WLP arrived in an area with fruits on the forest floor, they consumed them rapidly, leaving signs of their rooting on the forest floor, evidenced by excavation (Aliaga- Rossel, pers. observ.). Most of the seeds and seedlings of any species in areas disturbed by rooting were killed (Roldán, \& Simonetti, 2001; Aliaga- Rossel, pers. observ.). Such disturbed areas, with low seedling survival, compared to the total exclosures with their higher seedling survival, illustrate the great impact of peccaries on seed and seedling mortality. WLP consume and destroy seeds and seedlings of the chonta palm at higher rates than any rodent or small seed predator (Silman et al., 2003; Aliaga-Rossel, 2011b). However, in the WLP's long-distance movements, many patches or individual trees can be missed, which can create opportunities for seed predators with smaller home ranges such as agoutis to use those resources (AliagaRossel et al., 2008), burial of the seeds by rodents also provides protection from exposure to drying and the necessary conditions to germinate (Aliaga-Rossel, 2011a).

Seed removal within peccary exclosures in the unhunted forest was substantially less affected by other mammals. In the absence of WLP, rodents played an important role in seed removal and mortality in moderately hunted 
and hunted forests. In contrast, the unhunted forest had almost all seeds rapidly killed by WLP, and the proportion of seeds removed by rodents was significantly lower than the other treatments. As predicted, the absence of the main predator (Pérez, 2008) led to lower seed removal and mortality, and the mortality that occurred was probably caused mainly by rodents with lower impacts.

Seed removal rates can be variable, in Mexican forest fragments, Sánchez-Cordero and Martínez-Gallardo (1998), found that seed predation by small rodents was significant in the absence of medium- and large-sized mammals. Furthermore, Pérez (2008), detected a higher presence of agouti populations in the hunted area of Asunción del Quiquibey, caused probably by the reduction of carnivores, and the less preference by hunters for this species (Aliaga-Rossel, 2011b). The higher A. gratum seed density probably signifies more available resources for small rodents and insects. However, small rodents prey preferentially on small seeds; therefore, larger seeds are afforded a higher chance of survival, despite the abundance of small rodents (Donatti, Galetti, \& Guimarães, 2009). We assume that $A$. gratum like other palm species, depends partially on the agoutis for survival and germination, as seed dispersers and as seed predators (Smythe, 1989; Aliaga-Rossel et al., 2008; Donatti et al., 2009). Galetti et al. (2006) estimated for the fragmented Atlantic forest in Brazil that $75 \%$ of palm seeds are dispersed mainly by agouti (Dasyprocta punctata) and other rodents.

Insect predation rates were lower than expected. Other studies have reported insect predation as a major cause of seed mortality, with up to $50 \%$ of fallen fruits infected and depredated by insects (Terborgh, Losos, Riley, \& Riley, 1993; Cintra, 1997; QuirogaCastro, \& Roldán, 2001; Wright, 2003; Silvius, $\&$ Fragoso, 2002). The relative seed abundance strongly affects rates of seed infestation by insects (Quiroga-Castro, \& Roldán, 2001; Dracxler et al., 2011). By setting treatments far from parental trees and in low densities, the experimental design may have reduced the impacts of insect infestation. Conversely, higher insect predation was detected in the hunted forest than in the other forest types, because there are more rodents (squirrels) and fewer agoutis which depredate insect-infected seeds (Silvius, 2002; Jansen et al., 2010). The low overall insect infection rate may have been reduced by set plots in areas with low seed densities as presentd by Cintra (1997).

Similar to other studies of $A$. murumuru, Cintra and Horna (1997), found that seeds have a higher chance of survival in areas with reduced presence of WLP. In this study, few seeds outside the control and peccary exclosures were found in the vicinity, but there was no certainty of their fate or if they were removed from the exclosures or maybe can be brought from other areas.

On the other hand, food availability from other resources cannot be an explanation for the low removal rate in the hunted forest, because the hunted forest presented a similar composition of species and plant diversity as the unhunted forest. Palm density was higher in the hunted forest, however, the fruits dropped on the base of the parental palm were rotted, without any signs that mammals had been attracted to them (Aliaga-Rossel, 2011a). The experiments were set at the beginning of the peak of the fruiting season, the abundance of seeds on the forest floor may be enough to satiate small predators and leave more available resources and further increase the rate of insect depredation (Donatti et al., 2009; Dracxler et al., 2011). Therefore, it is also necessary to evaluate seed removal rates during low seed abundance, where competition between peccaries and other seed predators such as the agoutis may also be affected.

Palm seed survivorship was strongly affected by local densities of mammals; WLP were responsible for most seed loss of $A$. gratum. In a hunted forest, when peccaries were removed or drastically reduced, a higher seed survivorship is expected. Moreover, the effects of medium size rodents are difficult to determine and may depend on the composition and density of species within the forest 
(Donatti et al., 2009). Different forests close to human settlements will have different degrees of changes in wildlife composition, and such variation should result in different seed removal patterns and survivorship, causing changes in the dynamics of Astrocaryum seed removal across different scales within patches (i.e., near higher adult density) and ultimately influencing the structure and the composition of the local forest (Roldán, \& Simonetti, 2001; Beckman, \& Muller-Landau, 2007; Donatti et al., 2009; Holbrook, \& Loiselle, 2009).

\section{ACKNOWLEDGMENTS}

Thank to the Russel Train education program (WWF), to International Foundation for Science (IFS), and WCS - Bolivia and to Robert Wallace. Thank to Idea Wild for the equipment. Thank to my field assistant Heydi Montecinos and my field guides. Thank to David Duffy, Christopher Lepczyk, Andrew Taylor, Tamara Ticktin, Tom Ranker, Donald Drake. Thank to Sthephen Beck and Monica Moraes and the National Herbarium of Bolivia. Thank to Kirsten Silvius for her initial collaboration. Mark Gregory, Paula Capece Daniel Hagamman for the grammar review.

\section{RESUMEN}

La defaunación afecta la supervivencia de semillas Astrocaryum Gratum (Arecales: Arecaceae) en un bosque tropical sub-montano. Las relaciones planta-animal en bosques neotropicales son procesos complejos; los mamíferos medianos y grandes consumen frutos y semillas de varias especies, sin embargo, por su tamaño, la caza excesiva de estas especies puede resultar en bosques defaunados. Nuestro objetivo fue evaluar y comparar la remoción y sobrevivencia de semillas en un bosque sin caza, un bosque con caza moderada, y un bosque con mayor presión de caza. Para estudiar el proceso de defaunación, se examinó la interacción entre la palmera Astrocaryum gratum y el pecarí de labios blancos (Tayassu pecari). Para aislar y evaluar las tasas de remoción de semillas de A. gratum por mamíferos y para identificar las causas su mortalidad, bajo diferentes presiones de caza, se utilizó tratamientos de exclusiones para cada bosque; en cuatro parches de bosque distintos, colocamos tratamientos en bloques, compuesto por tres tipos de exclusiones (exclusión total, exclusión de pecarís y control). Distribuidos a $5 \mathrm{~m}$ de distancia entre ellos y los bloques separados por 50-75m. Establecimos 15 tratamientos en total para cada parche de bosque (5 bloques por parche), con 20 bloques dentro de cada tipo de bosque. Utilizando malla de alambre galvanizado, todos los vertebrados fueron excluidos (exclusión total). El segundo tratamiento fue la exclusión de pecarí. Estas fueron diseñadas para excluir pecarís, permitiendo el acceso sólo a pequeños vertebrados; los mamíferos grandes eran capaces de acceder a estas exclusiones por la parte superior abierta. Por último, el control permite el pleno acceso de todos los mamíferos. De forma oportunista, debajo de diferentes árboles adultos de $A$. gratum se recogieron frutas frescas. En cada tratamiento de exclusión, se colocaron veinte semillas de A. gratum, y su remoción fue registrada. En total, se analizaron 3600 semillas. La supervivencia de semillas fue menor en el bosque sin caza comparado con las áreas con caza moderada y bosques con una presión de caza mayor, que apoya la hipótesis de la importancia de los mamíferos en la remoción de semillas. De las 400 semillas iniciales en el "control" de cada uno de los tipos de bosques, hubo una diferencia significativa entre la remoción de semillas; con $1.75 \%$ de supervivencia en el bosque sin caza; $43.5 \%$ en bosque de caza moderada, y $48.5 \%$ en bosque con caza. La causa principal de la mortalidad de semillas fue pecaríes de labio blanco, mientras que en los bosques sin ellos, la eliminación principal fue causada por roedores y en el bosque de alta caza, se registró una la mayor infección de insectos. Los resultados indican que la defaunación afecta a supervivencia de semillas.

Palabras clave: defaunación, bosques semivacío, bosque vacío, Bolivia, palmera chonta.

\section{REFERENCES}

Aliaga-Rossel, E. (2011a). Phenology and Germination of the Chonta Palm, Astrocaryum gratum (Arecaceae) in a Sub-montane Forest. Palms, 55(2), 84-92.

Aliaga-Rossel, E. (2011b). The cascading effect of mammal species defaunation on seed and seedling survivorship as a result of hunting (Doctoral dissertation). University of Hawaii at Manoa, Hawaii.

Aliaga-Rossel, E., \& Painter, L. (2010). Tayassuidae and Suiidae. In R. B. Wallace, H. Gómez, Z. R. Porcel, \& D. I. Rumiz (Eds.), Distribución, Ecología y Conservación de los Mamíferos Medianos y Grandes de Bolivia. Chapter 22 (pp. 573-596). Centro de Ecología Difusión Simón I. Patiño: Santa Cruz, Bolivia.

Aliaga-Rossel, E., Kays, R. W., \& Fragoso, J. M. V. (2008). Home range use by Central American agoutis (Dasyprocta punctata) on Barro Colorado Island, Panama. Journal of Tropical Ecology, 24, 367-374.

Antonik, M. M. (2005). Population dynamics of Mauritia flexuosa: measuring the impact of white-lipped peccary foraging on plant community structure in a 
tropical forest (Master's thesis). State Univeristy of New York, New York.

Asquith, N. M., Wright, S. J., \& Clauss, M. J. (1997). Does mammal community composition control recruitment in neotropical forest? Evidence from Panama. Ecology, 78, 941-946.

Beckman, N. G., \& Muller-Landau, H. C. (2007). Differential effects of hunting on pre-dispersal seed predation and primary and secondary seed removal of two neotropical tree species. Biotropica, 39, 328-339.

Cintra, R. (1997). Leaf litter effects on seed and seedling predation of the palm Astrocaryum gratum and the legume tree Dipteryx micrantha in Amazonian forest. Journal of Tropical Ecology, 13, 709-725.

Cintra, R., \& Horna, V. (1997). Seed and Seedling survival of the palm Astrocaryum murumuru and the legume tree Dipterix micrantha in gaps in Amazonian forest. Journal of Tropical Ecology, 13, 257-277.

Donatti, C. I., Galetti, M., \& Guimarães, P. R. (2009). Seed dispersal and predation of an endemic Atlantic Forest palm Astrocaryum aculeatissimum in a gradient of seed disperser abundance. Ecological Research, 24, 1187-1195.

Dracxler, C. M., Pires, A. S., \& Fernandez, F. A. S. (2011). Invertebrate seed predators are not all the same: seed predation by Bruchine and Scolytine beetles affects palm recruitment in different ways. Biotropica, 43, 8-11.

Forget, P. M., \& Cuijpers, L. (2008). Survival and scatterhoarding of frugivores-dispersed seeds as a function of forest disturbance. Biotropica, 40, 380-385.

Fragoso, J. M. V. (1998). Home range and movement patterns of white-lipped peccary (Tayassu pecari) herds in the Northern Brazilian Amazon. Biotropica, 30, 458-469.

Galetti, M., Donatti, C. I., Pires, A. S., Guimaraes, P. R., \& Jordano, P. (2006). Seed survival and dispersal of an endemic Atlantic forest palm: the combined effects of defaunation and fragmentation. Botanical Journal Linnaean Society, 151, 141-149.

Galvez, D., \& Jansen, P. A. (2007). Bruchid beetle infestation and the value of Attalea butyracea endocarps for Neotropical rodents. Journal of Tropical Ecology, 23, 381-384.

Holbrook, K. M., \& Loiselle, B. A. (2009). Dispersal in a neotropical tree, Virola flexuosa (Myristicaceae): does hunting of large vertebrates limit seed removal? Ecology, 90, 1449-1455.

Janzen, D. H. (1970). Herbivores and the number of tree species in tropical forests. The American Naturalist, 104, 501-528.
Jansen, P. A., Elschot, K., Verkerk, P. J., \& Wright, S. J. (2010). Seed predation and defleshing in the agoutidispersed palm Astrocaryum standleyanum. Journal of Tropical Ecology, 26, 473-480.

Navarro, G., \& Maldonado, M. (2004). Geografia Ecológica de Bolivia: Vegetación y ambientes acuáticos. Santa Cruz: Ed. Centro de Ecología Simón I. Patiño.

Pérez, E. (2008). Bases para el monitoreo de mamíferos terrestres en bosques tropicales asociados a actividad turística y de cacería local, Reserva de la Biosfera y Tierra Comunitaria de Origen Pilón Lajas, Bolivia (Master's thesis). Universidad de Los Lagos, Chile.

Quiroga-Castro, V. D., \& Roldán, A. I. (2001). The fate of Attalea phalerata (Palmae) seeds dispersed to a Tapir Latrine. Biotropica, 33, 472-477.

Reyna-Hurtado, R., Taber, A., Altrichter, M., Fragoso, J. M., Keuroghlian, A., \& Beck, H. (2008). Tayassu pecari. In IUCN 2010. IUCN Red List of Threatened Species. Version 2010.4

Roldán, A. I., \& Simonetti, J. A. (2001). Plant-mammal interactions in tropical Bolivian forests with different hunting pressures. Conservation Biology, 15, 617-623.

Sánchez-Cordero, V., \& Martínez-Gallardo, R. (1998). Postdispersal fruit and seed removal by forestrodents in a lowland rainforest in México. Journal of Tropical Ecology, 14, 139-151.

Silman, M. R., Terborgh, J. W., \& Kiltie, R. A. (2003). Population regulation of a dominant rain forest tree by a major seed predator. Ecology, 84, 431-438.

Silvius, K. M. (2002). Spatio-temporal patterns of palm endocarp use by three Amazonian forest mammals: granivory or 'grubivory'? Journal of Tropical Ecology, 18, 707-723.

Silvius, K. M., \& Fragoso, J. M. V. (2002). Pulp handling by vertebrate seed dispersers increases palm seed predation by bruchid beetles in the northern Amazon. Journal of Ecology, 90, 1024-1032.

Smythe, N. (1989). Seed survival in the palm Astrocaryum standleyanum, evidence for dependence upon its seed dispersers. Biotropica, 21, 50-56.

Terborgh, J., Losos, E., Riley, M. P., \& Riley, M. B. (1993). Predation by vertebrates and invertebrates on the seeds of five canopy tree species of an Amazonian forest. Plant Ecology, 107-108, 375-386.

Vander Wall, S. B., Kuhn, K. M., \& Beck, M. J. (2005). Seed removal, seed predation and secondary dispersal. Ecology, 86, 801-806.

Wright, S. J. (2003). The myriad consequences of hunting for vertebrate and plants in tropical forests. Perspectives in Plant Ecology, Evolution and Systematics, 6, 73-86. 
